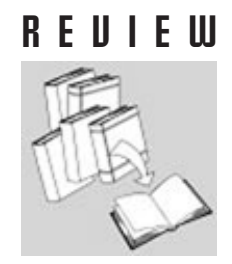

\title{
Next-generation treatment strategies for human papillomavirus-related head and neck squamous cell carcinoma: where do we go?
}

\author{
Nadine C. Olthof ${ }^{1,2 *,+}$, Jos M.J.A.A. Straetmans ${ }^{1,2+}$, Robert Snoeck ${ }^{4}$, \\ Frans C.S. Ramaekers ${ }^{2}$, Bernd Kremer ${ }^{1 *}$ and Ernst-Jan M. Speel ${ }^{2,3 *}$ \\ ${ }^{1}$ Departments of Otorhinolaryngology and Head and Neck Surgery, GROW-School for Oncology and \\ Developmental Biology, Maastricht University Medical Centre, Maastricht, the Netherlands \\ ${ }^{2}$ Departments of Molecular Cell Biology, GROW - School for Oncology and Developmental Biology, \\ Maastricht University Medical Centre, Maastricht, the Netherlands \\ ${ }^{3}$ Departments of Pathology, GROW-School for Oncology and Developmental Biology, Maastricht University \\ Medical Centre, Maastricht, the Netherlands \\ ${ }^{4}$ Rega Institute for Medical Research, Catholic University Leuven, Belgium
}

\section{SUMMARY}

Oncogenic human papillomavirus (HPV) is currently recognised as a major risk factor for the development of head and neck squamous cell carcinomas (HNSCC). HPV is mostly detected in tumours arising from the oropharynx and more specifically from the tonsil. HPV-related tumours display clinical and molecular characteristics that are distinct from HPV-unrelated tumours, which are generally induced by alcohol and tobacco abuse. Detection of biologically active HPV in HNSCC has prognostic relevance, which warrants the separate classification of HPV-induced tumours and is a prerequisite for further optimisation of treatment protocols for this distinct group. Current guidelines for the treatment of oropharyngeal squamous cell carcinoma (OPSCC) have not incorporated specific treatment modalities for HPV-related tumours. The development of such treatment options is still in a preclinical phase or in early clinical trials. Recent data on treatment response of OPSCC have been obtained by retrospectively analysing HPV-status and indicate that patients with HPV-related tumours show a favourable prognosis, independent of the type of treatment. These patients may benefit from de-intensified treatment, which should be assessed in prospective clinical trials. The development and future use of new antiviral and immunomodulatory therapeutics may be instrumental in this approach to improve survival rates and decrease disease-and-treatment-related morbidity. In this review we will focus on present therapeutic HPV-targeting strategies and discuss future directions for de-intensified treatment of HPV-positive HNSCC. Copyright (c) 2011 John Wiley \& Sons, Ltd.

Received: 1 July 2011; Revised: 29 July 2011; Accepted: 8 August 2011

${ }^{*}$ Corresponding author: Nadine C. Olthof, Department of Molecular Cell Biology (box 17), Maastricht University Medical Centre, PO Box 616, 6200 MD Maastricht, The Netherlands.

E-mail: nadine.olthof@maastrichtuniversity.nl

${ }^{+}$These authors contributed equally to this study as first authors.

These authors contributed equally to this study as senior authors.

\section{Abbreviations}

ANP, Acyclic Nucleoside Phosphonate; AZF, Artificial Zinc Fingers; CPP, Cell-Penetrating Peptide; CIN, Cervical Intraepithelial Neoplasia; CT, Chemotherapy; EGFR, Epithelial Growth Factor Receptor; EMT, Endothelial-to-Mesenchymal Transition; E-proteins, Early proteins; FISH, Fluorescence In Situ Hybridisation; HNSCC, Head and Neck Squamous Cell Carcinoma; HPMPC, [(S)-1-(3-hydroxy2-phosphonylmethoxypropyl)cytosine]; HPV, Human Papillomavirus; HR-HPV, High-Risk Human Papillomavirus; HSPG, Heparan Sulphate Proteoglycans; hTERT, Human Telomerase Reverse Transcriptase; ISH, In situ hybridisation; L-proteins, Late proteins; LRHPV, Low-Risk Human Papillomavirus; OPSCC, Oropharyngeal Squamous Cell Carcinoma; OSCC, Oral Squamous Cell Carcinoma;

\section{INTRODUCTION}

Head and neck cancer is a serious health care problem in many parts of the world [1]. The vast majority of head and neck cancers are squamous cell carcinomas originating from the mucosal epithelium lining the oral cavity, nasal cavity, pharynx and larynx [2]. In 2008, head and neck squamous cell carcinomas (HNSCC) were estimated to cause 480000 new cancer cases and 273000 cancer deaths worldwide [1]. Despite the fact that advances have been made in diagnosis and treatment, mortality rates have only marginally

PI, Protease Inhibitors; $p R b$, Retinoblastoma Tumour Suppressor protein; RNAi, RNA interference (small interfering RNA); RRP, Recurrent Respiratory Papillomatosis; TORS, Transoral Robotic Surgery; $T_{\text {regs, }}$ CD4+/CD25+ regulatory T-cells; UCSCC, Uterine Cervical Squamous Cell Carcinoma; VLP, Virus-Like Particles. 
decreased over the last decades and the 5-year survival rate currently ranges between $40 \%-60 \%$ [3]. Approximately $80 \%-90 \%$ of HNSCC develop in patients with a history of alcohol and tobacco abuse, including tobacco and betel quid chewing and snuff dipping [4]. These factors are also responsible for the process of 'field cancerisation' in the entire head and neck region [5], leading to multiple primary tumours in up to $40 \%$ of patients [6]. Patients without exposure to these risk factors account for $10 \%-20 \%$ of HNSCC. These tumours are predominantly associated with viral carcinogenesis, including infection with EBV in nasopharyngeal carcinomas [7] and, to a greater extent, infection with oncogenic human papillomavirus (HPV) in the oropharynx, in particular in the lingual and palatine tonsils. In the last decade, the incidence of HPV-related oropharyngeal squamous cell carcinoma (OPSCC) has increased relative to the total group of HNSCC $[4,8]$. Infection rates in OPSCC range from $20 \%$ to more than $90 \%$ in different studies, depending on geographical factors and the detection method used [9-12].

In this review, we will present the clinical and molecular features of HPV-positive HNSCC. Subsequently we will focus on the current knowledge of potential anti-HPV strategies and discuss the most promising modalities for the treatment of HPV-positive HNSCC.

\section{METHODS}

Besides relevant articles selected from the general literature concerning HPV-related carcinogenesis and references therein, specific literature on treatment options for HPV-related HNSCC was obtained by a bibliographical search in PubMed, Medline and Embase, from inception to May 2011, using the search term (HPV OR papillomavirus OR papilloma) AND (HNSCC OR 'head and neck cancer' OR oropharyngeal OR oropharynx OR oral OR pharyngeal OR pharynx OR buccal OR base of tongue OR tongue OR tonsillar OR tonsil OR floor of mouth OR mouth OR vallecula) AND (treatment $O R$ antiviral OR therapy) AND (cancer OR carcinoma OR tumour OR tumour OR neoplasm). This search yielded 1246 results in PubMed, 137 in Medline and 309 in Embase. Based on inspection of the title and/or abstract of these publications, 63 relevant papers on treatment options and some references therein were included in this review. Moreover, ongoing clinical trials concerning new therapeutic options for HPVrelated HNSCC were identified from the Cochrane
Controlled Trial Register and from the US National Institute of Health Clinical Trials (www.clinicaltrials. gov), yielding five relevant results.

\section{HUMAN PAPILLOMAVIRUS AND TUMOURIGENESIS}

\section{Human papillomavirus}

Human papillomaviruses are non-enveloped viruses, containing circular double-stranded DNA of approximately $8 \mathrm{~kb}$, that are highly epitheliotropic and known to infect both mucosal and cutaneous epithelia [13]. Papillomaviruses are species-specific and the human papillomavirus family can be classified into five genera and subdivided into 31 species and 120 types [14]. A subgroup of 15 HPV types is linked to the development of malignant lesions of mucosal and cutaneous epithelia, and is considered to comprise high-risk (HR) HPVs [15]. All HR-HPVs belong to the alpha-genus, including HPV-16 and HPV-18, which are found in $~ 50 \%$ and $~ 20 \%$ of cervical malignancies, respectively [16]. Differences in the capacity to deregulate cellular protein function by viral oncogenes E6 and E7 account for the carcinogenic properties of HR-HPV in comparison with low risk (LR) HPVs $[17,18]$. LR-HPV types, such as HPV-6 and HPV-11, are often found in benign mucosal lesions and are only sporadically associated with carcinomas. Human lesions in which HPV types of the alpha-genus appear to be involved are summarised in Table 1.

\section{Human papillomavirus replication and integration} The HPV life cycle is linked to the differentiation of the infected epithelial cell. HPV infection is initiated by binding of the virion L1 protein to heparan sulphate proteoglycans (HSPG) on segments of the basement membrane, which are exposed at sites of (micro)injury. This induces conformational changes and L2 cleavage finally resulting in binding of the L1 capsid protein to a so far undetermined cell surface receptor [19]. The cell adhesion receptor a6-integrin has been implicated to be this receptor [20], but does not seem to be essential for HPV infection. However, $\alpha 6$-integrin might be a matrix component closely associated with HSPG [21]. The circular HPV DNA comprises 8 genes, coding for six early (E) and two late (L) proteins (Figure 1). The E-proteins regulate and facilitate virus-replication and are expressed early after infection [22]. Oncoproteins E6 and E7 have a direct effect on several essential cellular processes, such as cell cycle and apoptosis 
Table 1. Involvement of human papillomavirus types of the alpha-genus in benign and malignant human lesions. The major human papillomavirus types for the different lesions are indicated in bold

\begin{tabular}{|c|c|c|}
\hline Lesion & HPV types found & References \\
\hline \multicolumn{3}{|l|}{ Head and neck benign } \\
\hline Focal Epithelial Hyperplasia & 13,32 & {$[176,177]$} \\
\hline Sinonasal papilloma & $6,11,18$ & {$[178,179]$} \\
\hline Laryngeal papilloma and dysplasia & $6^{1)}, 11,16,18$ & {$[180,181]$} \\
\hline Oral leukoplakia and lichen planus & $6,16,18,31,33$ & {$[182,183]$} \\
\hline \multicolumn{3}{|l|}{ Head and neck malignant } \\
\hline $\begin{array}{l}\text { Oropharyngeal squamous cell } \\
\text { carcinoma }\end{array}$ & $6,11,16,18,31,33,35$ & [52], this review \\
\hline Oral squamous cell carcinoma & 16,18 & {$[52,60]$} \\
\hline Laryngeal squamous cell carcinoma & $6,11,16,30$ & {$[52,60]$} \\
\hline Sinonasal carcinoma & 16,18 & [179] \\
\hline \multicolumn{3}{|l|}{ Anogenital } \\
\hline Anogenital $^{2)}$ benign lesions ${ }^{3)}$ & $6,11,16,18,31,33,53,56,58,66,83$ & {$[36,184]$} \\
\hline $\begin{array}{l}\text { Anogenital }{ }^{\S} \text { (squamous cell) } \\
\text { carcinoma }\end{array}$ & $6,11, \mathbf{1 6}, 18,31,33,45$ & [36] \\
\hline $\begin{array}{l}\text { Cervical intraepithelial neoplasia and } \\
\text { uterine cervical squamous cell carcinoma }\end{array}$ & $\begin{array}{l}6,11,16,18,31,33,35,39,45,51,52,56 \\
58,59,66,68,70,73,82\end{array}$ & {$[16,37]$} \\
\hline $\begin{array}{l}\text { Adenocarcinoma in situ and uterine cervical } \\
\text { adenocarcinoma }\end{array}$ & $\mathbf{1 6}, \mathbf{1 8}, 33,35,45,51,58,59$ & {$[185,186]$} \\
\hline \multicolumn{3}{|l|}{ Cutaneous } \\
\hline Common skin warts & $2,3,7,10,27,28$ & {$[15,187]$} \\
\hline Periungual squamous cell carcinoma & $16,26,33,51,56,73$ & {$[188,189]$} \\
\hline
\end{tabular}

${ }^{1)}$ The major HPV types for the different lesions are indicated in bold; ${ }^{2}$ including anal, vulvar, vaginal and penile lesions;

${ }^{3)}$ including warts, lichen sclerosis, squamous cell carcinoma in situ, adenocarcinoma in situ and intraepithelial neoplasia.

regulation. E6 promotes degradation of p53 through interaction with E6-associated protein (E6AP), an E3 ubiquitin ligase, and subsequent ubiquitination and proteasomal degradation. Amongst others, this alters transcription of p53 target genes and activates human telomerase reverse transcriptase (hTERT), resulting in cell survival and ultimately in genetic instability $[23,24]$. The oncoprotein E7 binds to the unphosphorylated retinoblastoma tumour suppressor protein $(\mathrm{pRb})$, which promotes the release of transcription factor E2F, leading to activation of the cell cycle and transition through the G1/S-phase, needed for DNAreplication [25-27]. As a consequence, $\mathrm{p} 16^{\mathrm{INK} 4 \mathrm{~A}}$ is upregulated but is unable to properly inhibit the cell cycle. Expression of oncoproteins E6 and E7 is tightly regulated by $\mathrm{E} 2$, the main regulator of viral gene transcription [28]. Molecular studies have shown that integration of HPV often leads to a disruption in the E1/E2 open reading frame and concurrent loss of the $\mathrm{E} 4$ and E5 and parts of the E2 and L2 genes [29]. E2 function can moreover be abrogated by epigenetic alterations of the viral genome such as methylation of the E2 binding site in the long control region [30]. Absence of E2 function results in upregulation of the expression of oncoproteins E6 and E7, which in turn leads to uncontrolled cell cycle progression (see Figure 1).

The major structural protein L1 of the HPV capsid is sufficient for self-assembly into a capsid, but entry of the virus into the cell is co-dependent on L2, the minor structural protein $[19,31]$.

Under normal circumstances, HPV maintains an episomal state, and infection with HPV is transient. In a recent prospective cohort study, the reported average duration of active episomal infection in the uterine cervix appears to be approximately 8 months [32]. Although uterine cervical HPV infection 


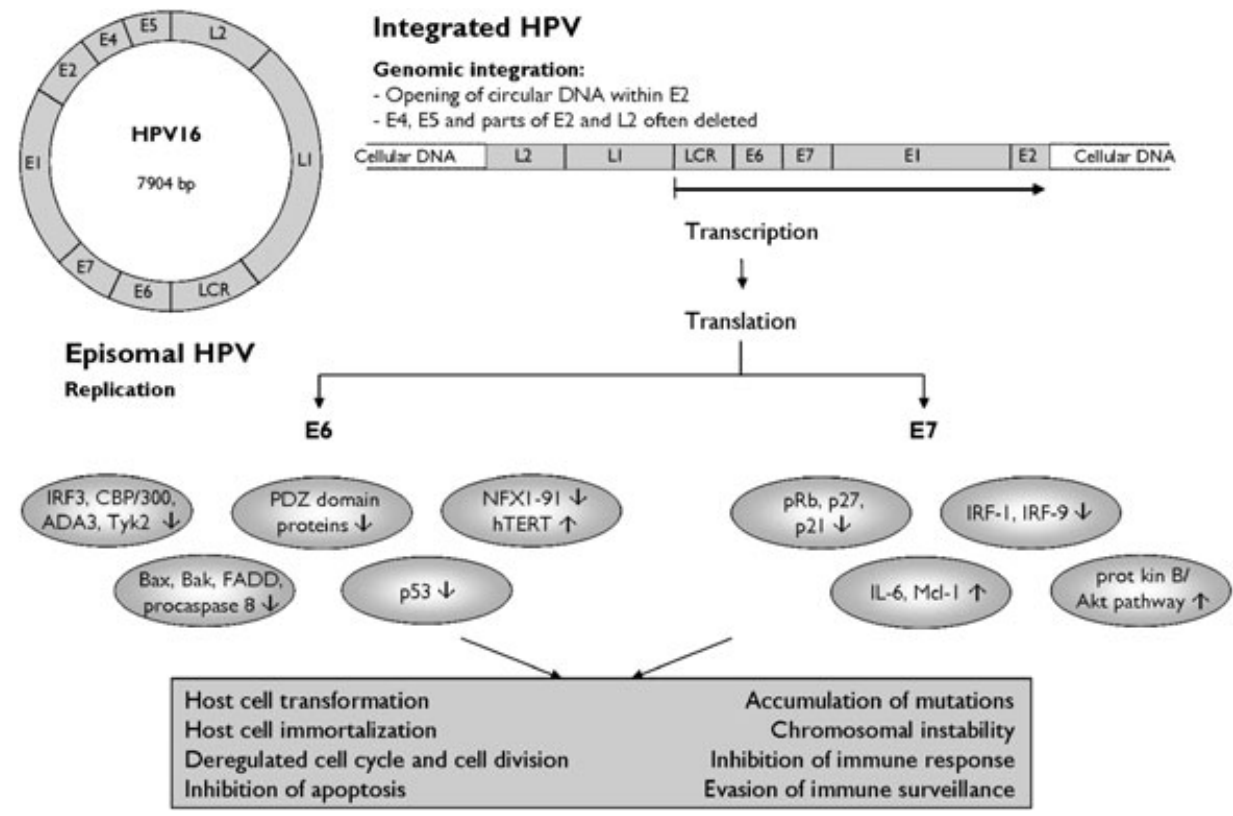

Figure 1. Structure of circular episomal and linear integrated HPV DNA. The HPV genome is usually present in many episomal copies in the nucleus of infected cells. In the transition to cancer, viral DNA often integrates in 1 or more copies into the host genomic DNA. During this process, the ring structure of the HPV-DNA molecule is most often opened within the E2 reading frame, frequently leading to deletion of E4 and E5 and part of E2 and L2. The subsequent upregulation of E6 and E7 oncoproteins results in deregulation of cell signalling pathways, which, amongst others, leads to increased cellular proliferation and inhibition of apoptosis. Based on [172-175]

prevalence decreases with increasing age [33], it is unclear whether age affects the duration of infection. Persistent infection, however, might lead to integration of the virus [34,35]. Numerous investigations have shown an etiological relationship between infection with HR-HPV infection and the development of uterine cervical squamous cell carcinomas (UCSCC) and other anogenital squamous cell carcinomas [36,37]. More than $90 \%$ of UCSCC contain and express HRHPV sequences, which are predominantly present in an integrated form $[38,39]$. HPV-16 is the most common HPV type and is detected in more than $50 \%$ of UCSCC, followed by HPV-18, HPV-33 and HPV-45 $[37,40]$ (Table 1).

The precise relationship between HR-HPV integration and head and neck carcinogenesis is less clear, partly because primary premalignant lesions of the oropharynx are seldom detected. Although controversial data have been reported [41-44], integration of HR-HPV in OPSCC is a prevailing finding.

\section{High-risk human papillomavirus in head and neck} squamous cell carcinoma

Patients with a history of HPV-related anogenital carcinomas, patients seropositive for HPV-16, and husbands of patients diagnosed with uterine cervical dysplasia or carcinoma in situ all show increased risk rates for developing OPSCC [45-47].

The involvement of HPV in head and neck tumourigenesis was first proposed by Syrjänen et al. [48], who showed histopathological features of HPV infections in $40 \%$ of patients, and HPV-positive nuclei in $20 \%$ of patients using immunohistochemistry. Since then many studies have provided evidence that infection with HR-HPV is a significant independent risk factor for HNSCC and is associated with high-risk sexual behaviour [9,10,49-51]. HR-HPV positive tumours are most frequently found in the oropharynx and are associated with HPV-16 in $>90 \%$ of cases $[9,49,52,53]$. Because patients with OPSCC often present with metastatic disease at first diagnosis, information on the persistence of oropharyngeal HPV infections and premalignant lesions in this region is scarce [54-56]. HPV prevalences of less than $1 \%$ have been found in tumour-negative tonsillar tissue samples, screened for HPV with PCR $[51,57,58]$.

\section{HR-HPV detection and tumour characteristics}

The reported overall incidence of HPV in OPSCC ranges from less than $20 \%$ to more than $90 \%$ in different studies. This variation depends on several factors, 
including geographical features, sample preparation and detection methods used but also the amount and manner of tobacco consumption depending on geographical location [9,12,54,59-61]. It has been shown that not all tumours tested positive for HPV DNA can be regarded as etiologically HPV-related [50,62]. A clinically relevant infection, that is, a transcriptionally active infection should be present, which can be demonstrated by detectable expression of the viral oncogenes E6 and E7 [63]. This correlates strongly with overexpression of the CDK inhibitor $\mathrm{p} 16^{\mathrm{INK} 4 \mathrm{~A}}$, which is considered a reliable surrogate marker for HR-HPV infection in most cases [41,64]. A reliable algorithm for HPV detection should thus start with $\mathrm{p} 16^{\mathrm{INK} 4 \mathrm{~A}}$ detection, followed by in situ hybridisation (ISH) and/or RT-PCR analysis of E6/E7 transcripts after HPV typing [41], as suggested by two recent reports $[59,65]$. A representative example of these analyses is shown in Figure 2.

The HPV-associated OPSCC are now considered to comprise a separate entity with typical clinical and molecular features. Table 2 summarises the major differences between HPV-positive and HPVnegative OPSCC.

The HPV-positive OPSCC are characterised by overexpression of oncoproteins E6 and E7 leading to degradation of $\mathrm{p} 53$ and $\mathrm{pRb}$, thereby inducing cell cycle and apoptosis deregulation. As a result, CDK inhibitors including $16^{\mathrm{INK} 4 \mathrm{~A}}$, p14 ${ }^{\mathrm{ARF}}$, p18 ${ }^{\mathrm{INK} 4 \mathrm{C}}$ and p21 ${ }^{\mathrm{Cip} 1 / \mathrm{WAF} 1}$ are upregulated, which subsequently leads to downregulation of cyclin D1 and inhibition of complex formation with CDK4 $[22,62,66,67]$. In HPV-negative tumours, cell cycle deregulation is established by p53 and pRb gene mutations, or alternatively by inactivation of $\mathrm{p} 16^{\mathrm{INK} 4 \mathrm{~A}}$ and $\mathrm{p} 14^{\mathrm{ARF}}$ gene expression through mutation, promoter hypermethylation or homozygous deletion [22], or activation of cyclin D1 expression via 11q13 amplification [68]. High expression of EGFR by transcriptional upregulation is generally present in this OPSCC subgroup [22,56,62,66-68]. Upregulation of EGFR expression is usually not seen in HPV-positive OPSCC [56,67,69-71].

In addition, global genome and protein scanning approaches have been and are being used to unravel DNA, mRNA, microRNA, and protein signatures specific for HPV-positive and HPV-negative OPSCC. So far, these studies revealed that HPV-positive tumours exhibit a relatively stable genome with $11 \mathrm{q}$ and $16 \mathrm{q}$ loss [72-74], and upregulate transcriptional activity of cell cycle regulators (as mentioned previously), transcription factors (e.g. TFDP2, ZNF238, TAF7L and RPA2) and DNA repair proteins (e.g. RFC4 and RFC5). Also, HPV-positive tumours show decreased expression of genes involved in immune responses (e.g. IFIT1, IFITM1-3, IFI6-16, IFI44L, OAS2 and IFN-א) [68,75-79]. In addition, these tumours differentially express microRNAs, and for example upregulate miR-363 (belonging to the oncogenic miR-106a-363 cluster) and downregulate miR-218. A recent proteome analysis comparing HPV-positive and HPV-negative oral squamous cell carcinomas (OSCC) reported upregulation of thioredoxin and epidermal-fatty acid binding protein [80]. Thioredoxin is an important redox-mediator that stimulates cell growth and inhibits apoptosis under adverse conditions, apparently including HPV infections, as also seen in cervical carcinomas. Epidermal fatty-acid binding protein, althoughmainly involved in fatty acid uptake, transport and metabolism, also functions in cellular signalling,
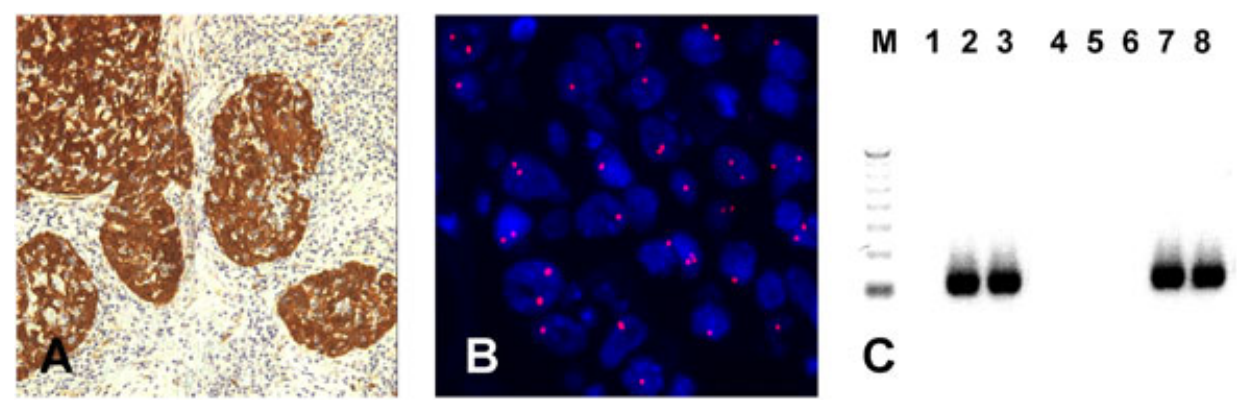

Figure 2. Representative examples of strong nuclear and cytoplasmic p16 ${ }^{\mathrm{INK} 4 \mathrm{~A}}$ immunostaining (A) and punctate nuclear HPV-16 FISH signals indicating viral integration (B) shown on paraffin embedded, formalin fixed tissue sections of oropharyngeal squamous cell carcinoma. An example of E6-specific HPV-16 RT-PCR products on a 1\% agarose gel, on RNA extracted from cell lines and fresh-frozen oropharyngeal squamous cell carcinoma tumour tissues, are shown in (C) 
Table 2. Clinical and molecular differences between OPSCC with or without HR-HPV *

HPV-positive

HPV-negative

Clinical characteristics

Preferred location

Degree of differentiation

Baseloid appearance

T-stage at diagnosis

Disease stage (TNM)

Average age

Tobacco (ab)use

Alcohol (ab)use

5-year disease free survival

Second primary tumours within 5 years

Local recurrences within 5 years

Molecular characteristics

E6/E7 expression

p53 downregulation

$\mathrm{pRb}$ downregulation

p16 ${ }^{\text {INK4A }}$ overexpression

p $14^{\mathrm{ARF}}$ overexpression

p18 ${ }^{\text {INK4C }}$ overexpression

p21 ${ }^{\text {Cip1/WAF1 }}$ overexpression

Cyclin D1 overexpression

EGFR overexpression

$\begin{array}{ll}\text { oropharynx } & \text { all sites } \\ \text { poorly differentiated } & \text { moderately to well differentiated } \\ \text { more often } & \text { less often } \\ \text { T1-2 } & \text { T3-4 } \\ \text { more advanced } & \text { less advanced } \\ \text { slightly younger than } 60 \text { years } & \text { slightly older than } 60 \text { years } \\ \text { low } & \text { high } \\ \text { low } & \text { high } \\ 70-90 \% & 30-60 \% \\ 0-10 \% & 10-15 \% \\ 10-20 \% & 25-55 \% \\ + & - \\ + & - \\ + & - \\ + & -{ }^{* *} \\ + & -{ }^{* *} \\ + & - \\ + & - \\ - & +{ }^{* * *} \\ - & +{ }^{* * *}\end{array}$

oropharynx

poorly differentiated

more often

T1-2

more advanced

slightly younger than 60 years

low

low

$0-10 \%$

*Summarised from [10,22,41,56,59,62,65-68,92,94,158,174,190-192].

**Inactivated by gene mutation, hypermethylation or homozygous deletion.

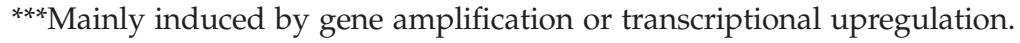

affecting differentiation, growth regulation and gene expression [80]. Although expression of 3q-specific genes has been reported as being specific for HPVpositive OPSCC, this finding remains to be confirmed, because extra copies of 3q-genes have been found in both HPV-positive and HPV-negative tumours [68,77].

\section{CURRENT TREATMENT OF OPSCC AND EFFECT OF HR-HPV STATUS ON TREATMENT RESPONSE}

\section{Current treatment modalities}

Current international clinical guidelines for HNSCC treatment mention HPV as a risk factor for OPSCC. The American National Comprehensive Cancer Network has suggested to include HPV detection in the diagnostic work-up of these tumours [81]. However, the treatment guidelines do not offer therapeutic modalities specific for HPV-related tumours. Current therapeutic options include surgery, radiotherapy, chemotherapy (CT), immunomodulatory therapies or combinations of the foregoing. Surgery as primary treatment avoids toxicity caused by radiotherapy and CT but causes loss of function, particularly in patients with larger tumours. The development of laser surgery and transoral robotic surgery (TORS) for OPSCC reduces functional morbidity as a consequence of three-dimensional visualisation and the ability to manipulate and perform reconstruction of the oropharynx without the need for an open surgical approach $[82,83]$. Regional infiltration of critical structures and unacceptable loss of function after surgery can classify a tumour as functionally or technically unresectable. In those cases, radiotherapy and/or CT is the treatment of choice [84] when aiming at restoring function, however with the disadvantage of therapy-related local and systemic side effects [85]. The final choice of treatment is based upon clinical variables such as tumour 
type, localisation and stage [86], age of the patient, general medical and psychomedical condition [81] and individual preferences of the patient.

\section{Effect of HR-HPV status on outcome}

In retrospective studies, HR-HPV- and/or $\mathrm{p} 16^{\mathrm{INK} 4 a}$ positive tumours have been found to respond better to multimodal therapies as compared to HPVnegative tumours, thereby favouring patient survival $[41,42,53,64,87,88]$. More recent retrospective studies have shown that this favourable outcome is independent of treatment modalities [89-95]. However, the heterogeneity of the HNSCC patient populations and consequent variability with regard to the HPV and/or p16 $6^{\mathrm{INK} 4 \mathrm{~A}}$ status, as well as applied treatment protocols, has most probably negatively influenced the association between HR-HPV status and outcome in these studies. It can be anticipated that the actual difference in clinical outcome between HPV-positive and HPV-negative cases will become even more pronounced when comparing a homogeneous population of OPSCC and application of reliable detection methods for clinically relevant HPV-infections. Prospective clinical trials are required to further validate HR-HPV presence as predictive factor for therapy outcome and to determine whether treatment de-intensification might improve quality of life while preserving the favourable clinical outcome in HPV-positive OPSCC patients [96,97].

An explanation for the favourable response may lie in the fact that, although the pRb-pathway and p53pathway are compromised in HPV-positive tumours, they retain some function, such that under the pressure of radiotherapy and/or CT, p53-mediated apoptotic pathways may still function. The presence of wild-type p53 in combination with low levels of Bcl-2/Bcl-xL and EGFR, which are features of HPV-positive tumours in non-smokers, may enhance this treatment advantage $[9,53,63,67,69,71]$. Moreover, limited tobacco and/or alcohol use reduces field cancerisation and the chance of developing a second primary tumour or distant metastasis in HPV-positive tumours [41,53,93], which underscores the need to investigate the effect of tobacco and alcohol exposure on the biological behaviour of HPV-positive OPSCC, as recently proposed [41,94].

Besides the overall better survival of patients with HPV-positive tumours, their treatment may be further improved by the implementation of strategies that either 1) promote the immune response to eradicate the virus, 2) inhibit viral DNA replication, 3) specifically target viral oncoproteins or 4) have an effect on deregulated signal transduction pathways specific for HPV-positive tumour cells. In the following section, we review these strategies, their mode of action and possible benefits for patients with HPV-induced HNSCC.

\section{PROPHYLACTIC AND THERAPEUTIC ALTERNATIVES FOR HPV-POSITIVE OPSCC}

\section{Immunomodulating therapies}

\section{Vaccination}

Two prophylactic vaccines, containing recombinant virus-like particles (VLP) composed of the L1 proteins of the respective HPV types [31] have been marketed recently, which are Cervarix ${ }^{\circledR}$ (GlaxoSmithKline, Brentford, Middlesex, TW8 9GS, United Kingdom) and Gardasil ${ }^{\circledR}$ (Merck, NJ, USA). Both vaccines have been FDA-approved for use in girls and young women $[98,99]$ and Gardasil $^{\circledR}$ has also been approved for use in men [100].

Cervarix $^{\circledR}$ is a bivalent vaccine that protects against infection with HPV-16 and HPV-18, whereas the quadrivalent vaccine Gardasi ${ }^{\circledR}$ provides protection against HPV-6, HPV-11, HPV-16 and HPV-18. Reports indicate that $\operatorname{Cervarix}^{\circledR}$ also offers cross-protection against HPV-31, HPV-45 and HPV-52 [101,102], and Gardasil ${ }^{\circledR}$ possibly against HPV-31 [103]. More robust crossprotection may be induced by adding L2 minor capsid proteins to the vaccine [104]. Both vaccines induce high antibody titers and seem to be well-tolerated and safe and provide $>90 \%$ protection in HPV-16 and HPV-18 in naïve females when given in three doses within six months [102,105]. Currently, only young HPV-naïve females are vaccinated because vaccination of women actively expressing HPV-16 or HPV-18 at study entry did not result in decreased development of cervical intraepithelial neoplasia (CIN) lesions [102,105]. However, vaccination with Gardasil $^{\circledR}$ also provided $>90 \%$ protection in women with evidence of past infection (seropositive and HPV DNA negative) with one or more of the HPV-types against which the vaccine is directed $[106,107]$. Long-term benefits of vaccination are not yet known, but it is hypothesised that vaccination could also strongly reduce the number of HPV-related OPSCC. This would indicate that HPV-naïve boys and young men should be vaccinated as well, because HPV-related OPSCC is diagnosed in males more often than in females $[61,69]$. However, seeing that patients usually present with HPV-related head and neck tumours from the fifth decennium of life onwards, the efficiency of vaccination in these patients will only become evident within a few decades. 
Patients with HPV-related disease may benefit from the development of therapeutic vaccines. These vaccines are designed to induce cell-mediated immunity against the overexpressed foreign viral oncoproteins, particularly E6 and E7. There are four classes of therapeutic vaccines: 1) live-vector based; 2 ) peptide/protein based; 3) nucleic acid based; and 4) whole cell vaccines (for a comprehensive review see [108]). In anogenital and uterine cervical lesions therapeutic vaccination has been shown to generate specific immunological and clinical responses, including complete regression of the lesion in $22 \%$ of patients with CIN III lesions as reported in a study using a fusion protein-based vaccine [109-111]. A preclinical study using a DNA-based vaccine demonstrated that such an approach for therapeutic vaccination was efficacious in a mouse model of HPV-related HNSCC [112]. Clinical trials to evaluate the effectiveness of therapeutic vaccination in HPVrelated HNSCC are ongoing $[113,114]$.

\section{Interferon}

Interferons are cytokines that are produced by many cell types in response to infection with bacteria, viruses and parasites [115]. Two classes of IFNs can be distinguished: Class I consists of IFN- $\alpha$ and IFN- $\beta$, and Class II consists of IFN $\gamma$. Class I IFNs are secreted from infected cells and bind to the ubiquitously expressed heterodimeric interferon receptor. Binding of $\operatorname{IFN} \alpha / \beta$ to the interferon receptor induces the transcription of several host cell proteins that inhibit viral replication in the infected epithelial cell, and leads to activation and the production of IFN $\gamma$ in dendritic cells. IFN $\gamma$ can also be produced by activated Th1 cells. Both classes of IFNs possess antiviral and antiproliferative properties. IFN $\gamma$ can also activate macrophages and natural killer lymphocytes, and induce translocation of the major histocompatibility complex Classes I and II to the cell membrane [115]. The interferon response, however, is suppressed upon HPV infection because several HPV proteins (E1, E6 and E7) interfere with the IFN signal transduction cascade by binding to, for example, Tyk2 kinase, IRF-1 and IRF-3, p48 and p56 leading to downregulation of the levels of IFN-inducible genes, such as TNSFS10, IFIT1 and IFI54 [78,116,117].

Despite this, a successful immune response to HPV is generally seen in healthy individuals, as for example reported in the studies of van der Burg and co-workers $[118,119]$, showing high frequencies of circulating CD4+ T-helper cells reacting with HPV16 E2 and E6, indicating a cell-mediated Th1 immune response. In persisting lesions, application of IFN therapy may restore antiviral defence mechanisms, thereby supporting effective treatment of HPV-infected lesions. IFN therapy proved to be beneficial in HPV infections such as condylomata acuminata $[119,120]$, whereas the use of IFN therapy in HPV-associated anogenital intraepithelial neoplasia has been assessed in several studies with contradicting results. Improved outcome for IFN-treated patients was shown in some studies [121,122], whereas others reported no change in response rates between treated patients and controls $[123,124]$. This might be attributed to the fact that local application seems to achieve better responses than systemic application [120]. In addition, it seems that IFN therapy can eradicate episomal HPV infection but leads to growth advantage for cells containing integrated HPV [125,126]. IFN-induced upregulation of p56, which blocks HPV replication by binding to the E1 protein and inhibits its helicase activity, may explain this effect on episomal infection $[127,128]$. Loss of (parts of) E1 and E2 by viral integration, resulting in upregulation of E6 and E7 as stated previously could explain the lack of effect of IFN treatment in these cells and their selective growth advantage. On the contrary, IFN was also shown to increase viral early gene transcription in a cell model [129]. In recurrent respiratory papillomatosis (RRP) a long-term response to IFN- $\alpha$ therapy was seen in patients with HPV-6-related papillomas, but patients with HPV-11-related papillomas were much less responsive to IFN therapy [130]. In conclusion, the beneficial effects of IFN therapy seem to be limited to episomal infections, which limits the applicability of this therapy in HPV-positive carcinomas.

\section{Antiviral therapy}

\section{Cidofovir}

Cidofovir [(S)-1-(3-hydroxy-2-phosphonylmethoxypropyl)cytosine] (HPMPC) is a nucleoside analogue of deoxycitidine monophosphate with a remarkably broad spectrum of antiviral activities directed against DNA viruses, including HPV and polyoma [131]. After intracellular double phosphorylation, the structure resembles $\mathrm{dCTP}$ and can act as a competitive substrate. After removal of the diphosphate group cidofovir can be incorporated into viral DNA during replication, resulting in selective antiviral activity for those viruses encoding their own DNA polymerase. Viral DNA polymerases, for instance cytomegalovirus, display greater affinity for cidofovir than human cellular DNA polymerases. Although HPVs do not produce viral DNA polymerases, cells infected with HPV show enhanced 
susceptibility to cidofovir-induced apoptosis as compared to non-infected cells for a yet unknown reason [132,133].

In 1998, it was shown by Andrei et al. that acyclic nucleoside phosphonate (ANP) analogues, such as cidofovir, show a selective antiproliferative effect in HPV-bearing tumour cell lines CK-1, SiHa, CaSki and HeLa [134]. This effect is partly induced by its non-selective toxicity to rapidly dividing cells $[134,135]$. Apoptosis might also be induced by accumulation of the tumour suppressor proteins p53 and p21 Cip1/WAF1 [132,133], although an increase in p53 expression was not found in the HNSCC cell line UPCI:SCC090 [136]. However, by combining cidofovir with radiotherapy, the radiosensitivity of UPCI:SCC090 and other HPVcontaining cell lines could be enhanced in vitro $[132,136]$, as well as in vivo in nude mouse xenografts [132]. CT combined with cidofovir also yielded a synergystic effect in an HNSCC cell line model [137]. One study expressed concern about using cidofovir for the treatment of RRP [138], as it demonstrated high malignancy transformation rates in rats and cell lines. In humans, this effect has not been reported, and cidofovir is already applied as an effective adjuvant therapy for HPV-induced RRP in humans [139].

For the treatment of various HPV-related lesions the route of administration may be an important factor. Cidofovir can be applied systemically or topically or injected intralesionally. Although concern was raised about possible nephrotoxicity in systemic use, this side-effect can be greatly diminished by administration of probenecid and prehydration with saline solution [140].

In a clinical setting, it was shown that local therapy with cidofovir gel resulted in complete or partial regression of uterine CIN II and III lesions $[141,142]$ as well as vulvar and other intraepithelial neoplasms $[143,144]$. On the other hand, intralesional treatment with cidofovir of one patient with an invasive carcinoma in the respiratory tract and a history of RRP only lead to minor clinical effects, limited to the superficial portion of the tumour [145].

Clinical trials using cidofovir as an adjuvant therapy in cervical cancer have started [146], but trials for its application in HNSCC have to be initiated.

\section{Interfering RNAs}

The RNA interference (RNAi) can be used to inactivate gene expression and so far encouraging results have been reported for the treatment of HPV-related carcinomas in vitro as well as in vivo. Chen and coworkers, for example, reported a $50 \%$ reduction of E7 mRNA expression in HPV-6b/11 E7-expressing mouse tumour models [147]. RNAi against HPV-16 E6 and/or E7 has been shown to degrade these mRNAs leading to decreased expression of the gene products in both cervical as well as HNSCC cell line models. This resulted in restoration of $\mathrm{pRb}$ function and upregulation of $\mathrm{p} 53$ and p21 Cip1/WAF1, leading to substantial apoptotic cell death [148-150]. RNAi against HPV-18 E6 and E7 has also seemed to possess antitumour activity by retarding the growth of HeLa-cell induced tumours in NOD-SCID mice [151] and to enhance the chemotherapeutic effect of cisplatin in HeLa cells in vitro [152].

\section{Molecular therapy based on cellular targets}

Because inactivated tumour suppressor gene products such as p53 and p16 ${ }^{\mathrm{INK} 4 \mathrm{~A}}$ are difficult to restore by molecular therapy, many studies have focussed on the identification of oncogenes and deregulated cell signalling pathways in HNSCC. Key pathways involved in HNSCC include EGFR, PI3K-PTEN-AKT, TGF $\beta$ and NF- $\kappa \mathrm{B}$ signalling for which inhibitors are available, for example, the anti-EGFR antibody cetuximab [153], or being tested in several clinical trials (for reviews, see [72,73]).

In cervical cancer EGFR overexpression has been shown to negatively affect overall survival in patients treated with radiotherapy [154]. Anti-EGFR therapy using cetuximab lead to a therapeutic response in $12.5 \%$ of patients with uterine cervical SCC [155]. Also in HNSCC, including HPV-positive OPSCC, overexpression of EGFR correlates with poor prognosis $[67,70,71]$, although only a small subgroup of HPV-positive OPSCC exhibit EGFR protein accumulation $[67,71]$. Large prospective trials with anti-EGFR therapy in HPV-positive HNSCC have been initiated [97], although its efficacy is most probably limited to the small subgroup of EGFRexpressing tumours.

Alternatively, the PI3K-PTEN-AKT pathway might be an efficient target because HPV-positive OPSCC show extra copies of chromosome $3 q$ in up to two-thirds of cases [68], including the $3 q 26$ locus, harbouring the PI3K gene.

Tumour angiogenesis and metastases are correlated to upregulation of the TGF- $\beta$ and NFкB pathways [156,157]. HPV positive OPSCC have been shown to metastasise in an earlier stage compared to HPV negative OPSCC [158], indicating earlier 
endothelial-to-mesenchymal transition (EMT), which is characterised by the expression of vimentin, dowregulation of E-cadherin and upregulation of $\beta$-catenin [159]. This suggests that EMT might be related to upregulation of these pathways and that particularly HPV-positive OPSCC might be a potentially interesting group for NFkB-inhibitors, for which a clinical trial has recently started [160].

Increased degradation of cell cycle regulatory proteins p53 and pRb by the oncoproteins E6 and E7, can be inhibited by targeting the proteasomal pathway. Ritonavir, a protease inhibitor (PI) that is used in HIV-infected patients, inhibits the chemotryptic activity of the human cellular $20 \mathrm{~S}$ proteasome while increasing the tryptic activity [161], resulting in reduced protein degradation. It was shown to enhance antitumour activity when combined with radiotherapy both in vitro and in vivo in a Hep-2 head and neck carcinoma model [161], later however shown to be contaminated with HeLa cells. The PI Lopinavir was shown to restore p53 expression and to induce apoptosis in $\mathrm{SiHa}$ cells [162]. Athough several clinical trials have evaluated the effectiveness of PIs in the treatment of HIV, clinical trials in the treatment of HPV-related disease have not been initiated.

Finally, replication of the HPV virus can be targeted. In episomal HPV infection, replication is initiated by binding of $\mathrm{E} 2$ to its origin of replication [54]. In human transcription factors, the most commonly found DNA binding motifs are zinc fingers. Recently, artificial zinc fingers (AZF) have been developed as a potent new inhibitor of HPV [163]. When linked to a cell-penetrating peptide (CPP) these AZF were shown to inhibit HPV-18 for 97\% [164]. However, because the CPP-AZF is designed to prevent E2 from binding to its origin of replication, they are only effective in episomal HV infection.

\section{DISCUSSION}

The past decade has provided evidence for a biological association between oncogenic HPV and OPSCC. HPV-induced OPSCC show molecular and clinical features that are clearly different from tobacco-andalcohol-induced tumours and these differences seem to underlie prognostic differences between both tumour subgroups. Independent of treatment modality, patients with HPV-positive tumours demonstrate up to $30 \%$ better survival rates. In the past decennia, intensification of treatment was the most important strategy to improve survival of patients with HNSCC.
However intensification of treatment, combined with increased side effects, is finally reaching the maximum tolerance of the patient and this limits the intensity of treatment. Until now, no differentiation of therapeutic strategies has been made between the HPV-positive and HPV-negative subgroups in international guidelines on OPSCC treatment [81]. Because of the clinical and molecular differences between both groups, the question arises whether HPV-positive tumours need equally intensive treatment protocols as their HPV-negative counterparts. Moreover, additional antiviral therapeutic strategies can possibly improve survival without increasing therapy-related morbidity in HPV-positive tumours. In current and future studies. we should, therefore, aim at improving the quality of life in patients by de-intensification regimens in selected cases. Next-generation treatment strategies for HPV-associated cancers should focus on decreasing adjuvant radiotherapy and chemotherapy, whether or not combined with therapeutic options specifically targeting HPV. Assessing which therapy is most effective will finally lead to a more personalised approach for individual patients.

Immunomodulating therapies, such as IFN therapy, may have beneficial effects, but this seems to be limited to episomal infections. This conveys the need to reliably establish the integration status of HPV infection. That this criterion has not yet been met becomes apparent when observing the reported integration frequencies, which range from $0 \%$ to $100 \%$, depending on the population studied and methods used [41,42].

Tumour-specific host responses could also be enhanced by depletion of CD4+/CD25+ regulatory T-cells $\left(\mathrm{T}_{\text {regs }}\right)$. Increased expression of $\mathrm{T}_{\text {regs }}$ was shown in patients with CIN and cervical cancer $[165,166]$. It is hypothesised that the enlarged population of $\mathrm{T}_{\text {regs }}$ suppresses HPV-specific immunity and inhibits tumour-specific T-cell responses. Upregulated $\mathrm{T}_{\text {regs }}$ have already been depleted using an anti-CD25 antibody, such as PC61 [167].

Other immunomodulating therapies such as imiquimod, a topical immune response modifier that has successfully been used in the treatment of anogenital lesions with episomal HPV infections [168], are thought to be unsuitable for application in HPV-related HNSCC and RRP. Application to cutaneous epithelia is known to induce local inflammatory responses and pain, which will be enhanced in mucosal epithelia. Moreover, the substance cannot be controlled to reach all tumour parts when 
topically applied, and, like IFN-therapy, will at best lead to eradication of only episomal HPV infections, whereas a large proportion of HPV-positive HNSCC show viral integration [169].

Antiviral therapies such as cidofovir and RNAi have already shown promising results and are expected to have progressive impact on the treatment of HPV-associated lesions. Cidofovir has been tested in cervical cancers and RRP, where it has been applied topically or intralesionally in most studies. It has been shown that combining IFN therapy with cidofovir could enhance the antiviral and antiproliferative effects of either substance alone, and it is postulated that adding IFN therapy could further improve the auspicious effects of cidofovir combined with CT and/or radiotherapy [170]. Furthermore, it is recommended to assess the effects of cidofovir as adjuvant therapy in the treatment of HPV-associated HNSCC in a larger, prospective clinical trial.

The RNAi treatment, although tested in mouse models, has not yet been evaluated for use in human HPV-associated HNSCC. Such studies can, however, be expected in the near future, judging from patents referring to the use of oligonucleotides in the treatment of HPV infections (see for example [171]).

Therapeutic approaches based on the molecular profile of the tumours are emerging in an adjuvant setting. However, one of the major drawbacks of such an approach is that the applicability should be assessed for each individual patient. For example, cetuximab can only be applied in a small subgroup of patients with HNSCC because HPV-positive tumours tend to show a low EGFR expression. In the current practice, Cetuximab is already used for larger non-resectable head and neck tumours, irrespective of HPV status. With regard to PIs and AZFs, no clinical studies have yet tested the applicability of these therapeutic options in the treatment of HPVrelated carcinomas.

Because therapeutic vaccination is expected to have minimal side effects it can be combined with other therapeutic approaches, such as radiotherapy and/ or CT, to obtain synergistic effects. However, therapeutic vaccines are still in a developmental stage.

Although a significant reduction in the burden of HPV-related diseases can be anticipated if prophylactic vaccination will live up to its promises, only HPV-naïve females are currently vaccinated. We firmly believe that young HPV-naïve boys should also be vaccinated in order to achieve optimal protection, although it needs to be validated whether vaccination is cost-effective.

In conclusion, we can state that although it has become evident that HPV-positive HNSCC have a better prognosis that their HPV-negative counterparts, the choice of therapy for these two subgroups of HNSCC will strongly depend on the outcome of ongoing clinical trials, including de-intensification protocols and implementation of treatment options based on new insights into the molecular biology of HPV-infection.

\section{CONFLICT OF INTEREST}

The authors have no competing interest.

\section{REFERENCES}

1. Ferlay J, Shin HR, Bray F, et al. Estimates of worldwide burden of cancer in 2008: GLOBOCAN 2008. International Journal of Cancer 2010; 127: 2893-2917. DOI: 10.1002/ijc.25516

2. Johnson N, Franceschi S, Ferlay J, et al. Oral Cavity and Oropharynx. In: Pathology and Genetics Head and Neck Tumours, Barnes L, Eveson J, Reichart P, Sidransky D (ed). IARC Press: Lyon, 2005; 163-208.

3. Jemal A, Siegel R, Ward E, et al. Cancer statistics, 2008. CA: a Cancer Journal for Clinicians 2008; 58: 71-96.

4. Sturgis EM, Cinciripini PM. Trends in head and neck cancer incidence in relation to smoking prevalence: an emerging epidemic of human papillomavirus-associated cancers? Cancer 2007; 110: 1429-1435. DOI: 10.1002/ cncr.22963
5. Braakhuis BJ, Tabor MP, Kummer JA, et al. A genetic explanation of Slaughter's concept of field cancerization: evidence and clinical implications. Cancer Research 2003; 63: 1727-1730.

6. Haughey BH, Gates GA, Arfken CL, et al. Meta-analysis of second malignant tumors in head and neck cancer: the case for an endoscopic screening protocol. Annals of Otology, Rhinology and Larynology 1992; 101: 105-112.

7. Pattle SB, Farrell PJ. The role of Epstein-Barr virus in cancer. Expert Opinion on Biological Therapy 2006; 6: 1193-1205. DOI: 10.1517/ 14712598.6.11.1193

8. Carvalho AL, Nishimoto IN, Califano JA, et al. Trends in incidence and prognosis for head and neck cancer in the United States: a site-specific analysis of the SEER database. International Journal of Cancer 2005; 114: 806-816. DOI: 10.1002/ijc.20740

9. Hafkamp HC, Speel EJ, Haesevoets A, et al. A subset of head and neck squamous cell carcinomas exhibits integration of HPV 16/18 DNA and overexpression of p16INK4A and p53 in the absence of mutations in p53 exons 5-8. International Journal of Cancer 2003; 107: 394-400. DOI: 10.1002/ijc.11389

10. Ragin CC, Taioli E. Survival of squamous cell carcinoma of the head and neck in relation to human papillomavirus infection: review and meta-analysis. International Journal of Cancer 2007; 121: 1813-1820. DOI: 10.1002/ijc.22851

11. Fakhry C, Gillison ML. Clinical implications of human papillomavirus in head and neck cancers. Journal of Clinical Oncology 
2006; 24: 2606-2611. DOI: 10.1200/ JCO.2006.06.1291

12. Nasman A, Attner P, Hammarstedt L, et al. Incidence of human papillomavirus (HPV) positive tonsillar carcinoma in Stockholm, Sweden: an epidemic of viralinduced carcinoma? International Journal of Cancer 2009; 125: 362-366. DOI: 10.1002/ijc. 24339

13. de Villiers EM, Fauquet C, Broker TR, et al. Classification of papillomaviruses. Virology 2004; 324: 17-27. DOI: 10.1016/j.virol. 2004.03.033

14. Bernard HU, Burk RD, Chen Z, et al. Classification of papillomaviruses (PVs) based on 189 PV types and proposal of taxonomic amendments. Virology 2010; 401: 70-79. DOI: 10.1016/j.virol.2010.02.002

15. World Health Organization. Human papillomaviruses: IARC Monographs on the evaluation of carcinogenic risks to humans. International Agency for Research on Cancer: Lyon, 2007

16. Munoz N, Bosch FX, de Sanjose S, et al. Epidemiologic classification of human papillomavirus types associated with cervical cancer. The New England Journal of Medicine 2003; 348: 518-527.

17. Hiller T, Poppelreuther S, Stubenrauch F, et al. Comparative analysis of 19 genital human papillomavirus types with regard to p53 degradation, immortalization, phylogeny, and epidemiologic risk classification. Cancer Epidemiology, Biomarkers $\mathcal{E}$ Prevention 2006; 15: 1262-1267. DOI: 10.1158/1055-9965.EPI-05-0778

18. Pim D, Banks L. Interaction of viral oncoproteins with cellular target molecules: infection with high-risk vs low-risk human papillomaviruses. APMIS 2010; 118: 471-493. DOI: 10.1111/j.1600-0463.2010.02618.x

19. Schiller JT, Day PM, Kines RC. Current understanding of the mechanism of HPV infection. Gynecologic Oncology 2010; 118: S12-17. DOI: 10.1016/j.ygyno.2010.04.004

20. Yoon CS, Kim KD, Park SN, et al. alpha(6) Integrin is the main receptor of human papillomavirus type 16 VLP. Biochemical and Biophysical Research Communications 2001; 283 : 668-673. DOI: $10.1006 /$ bbrc. 2001.4838

21. Horvath CA, Boulet GA, Renoux VM, et al. Mechanisms of cell entry by human papillomaviruses: an overview. Virology Journal 2010; 7: 11. DOI: 10.1186/1743-422X-7-11
22. zur Hausen H. Papillomaviruses and cancer: from basic studies to clinical application. Nature Reviews. Cancer 2002; 2: 342-350. DOI: $10.1038 /$ nrc798

23. McMurray HR, McCance DJ. Human papillomavirus type 16 E6 activates TERT gene transcription through induction of c-Myc and release of USF-mediated repression. Journal of Virology 2003; 77: 9852-9861. DOI: 10.1128/JVI.77.18.98529861.2003

24. Liu X, Dakic A, Zhang Y, et al. HPV E6 protein interacts physically and functionally with the cellular telomerase complex. Proceedings of the National Academy of Sciences of the United States of America 2009; 106: 18780-18785. DOI: 10.1073/ pnas.0906357106

25. Funk JO, Waga S, Harry JB, et al. Inhibition of CDK activity and PCNA-dependent DNA replication by $\mathrm{p} 21$ is blocked by interaction with the HPV-16 E7 oncoprotein. Genes E Development 1997; 11: 2090-2100. DOI: 10.1101/gad.11.16.2090

26. Jones DL, Alani RM, Munger K. The human papillomavirus E7 oncoprotein can uncouple cellular differentiation and proliferation in human keratinocytes by abrogating p21Cip1-mediated inhibition of CDK2. Genes E Development 1997; 11: 2101-2111. DOI: 10.1101/gad.11.16.2101

27. Zerfass-Thome K, Zwerschke W, Mannhardt $\mathrm{B}$, et al. Inactivation of the cdk inhibitor p27KIP1 by the human papillomavirus type 16 E7 oncoprotein. Oncogene 1996; 13: 2323-2330.

28. Dowhanick JJ, McBride AA, Howley PM. Suppression of cellular proliferation by the papillomavirus E2 protein. Journal of Virology 1995; 69: 7791-7799.

29. Ziegert C, Wentzensen N, Vinokurova S, et al. A comprehensive analysis of HPV integration loci in anogenital lesions combining transcript and genome-based amplification techniques. Oncogene 2003; 22: 3977-3984. DOI: 10.1038/sj.onc. 1206629

30. Park IS, Chang X, Loyo M, et al. Characterization of the methylation patterns in human papillomavirus type 16 viral DNA in head and neck cancers. Cancer Prevention Research (Philadelphia, Pa.) 2011; 4: 207-217. DOI: 10.1158/1940-6207.CAPR10-0147
31. Stanley MA. Human papillomavirus vaccines. Reviews in Medical Virology 2006; 16: 139-149. DOI: 10.1002/rmv.498

32. Goodman MT, Shvetsov YB, McDuffie K, et al. Prevalence, acquisition, and clearance of cervical human papillomavirus infection among women with normal cytology: Hawaii human papillomavirus cohort study. Cancer Research 2008; 68: 8813-8824. DOI: 10.1158/0008-5472.CAN-08-1380

33. Bosch FX, Lorincz A, Munoz N, et al. The causal relation between human papillomavirus and cervical cancer. Journal of Clinical Pathology 2002; 55: 244-265.

34. Hopman AH, Smedts F, Dignef W, et al. Transition of high-grade cervical intraepithelial neoplasia to micro-invasive carcinoma is characterized by integration of HPV 16/18 and numerical chromosome abnormalities. The Journal of Pathology 2004; 202: 23-33. DOI: 10.1002/path.1490

35. Vinokurova S, Wentzensen N, Kraus I, et al. Type-dependent integration frequency of human papillomavirus genomes in cervical lesions. Cancer Research 2008; 68: 307-313. DOI: 10.1158/0008-5472.CAN07-2754

36. De Vuyst H, Clifford GM, Nascimento MC, et al. Prevalence and type distribution of human papillomavirus in carcinoma and intraepithelial neoplasia of the vulva, vagina and anus: a meta-analysis. International Journal of Cancer 2009; 124: 1626-1636. DOI: 10.1002/ ijc.24116

37. Smith JS, Lindsay L, Hoots B, et al. Human papillomavirus type distribution in invasive cervical cancer and high-grade cervical lesions: a meta-analysis update. International Journal of Cancer 2007; 121: 621-632. DOI: 10.1002/ijc.22527

38. Cricca M, Morselli-Labate AM, Venturoli $\mathrm{S}$, et al. Viral DNA load, physical status and E2/E6 ratio as markers to grade HPV16 positive women for high-grade cervical lesions. Gynecologic Oncology 2007; 106: 549-557. DOI:10.1016/j.ygyno.2007.05.004

39. Guo M, Sneige N, Silva EG, et al. Distribution and viral load of eight oncogenic types of human papillomavirus (HPV) and HPV 16 integration status in cervical intraepithelial neoplasia and carcinoma. Modern Pathology 2007; 20: 256-266. DOI:10.1038/modpathol.3800737 
40. Sigurdsson K, Taddeo FJ, Benediktsdottir $\mathrm{KR}$, et al. HPV genotypes in CIN 2-3 lesions and cervical cancer: a populationbased study. International Journal of Cancer 2007; 121: 2682-2687. DOI: 10.1002/ ijc. 23034

41. Hafkamp HC, Manni JJ, Haesevoets A, et al. Marked differences in survival rate between smokers and nonsmokers with HPV 16-associated tonsillar carcinomas. International Journal of Cancer 2008; 122: 2656-2664. DOI: 10.1002/ijc.23458

42. Mellin H, Dahlgren L, Munck-Wikland E, et al. Human papillomavirus type 16 is episomal and a high viral load may be correlated to better prognosis in tonsillar cancer. International Journal of Cancer 2002; 102: 152-158. DOI: 10.1002/ijc.10669

43. Koskinen WJ, Chen RW, Leivo I, et al. Prevalence and physical status of human papillomavirus in squamous cell carcinomas of the head and neck. International Journal of Cancer 2003; 107: 401-406. DOI: 10.1002/ijc. 11381

44. Ukpo OC, Moore EJ, Smith DI. Human papillomavirus and oropharyngeal cancer. The New England Journal of Medicine 2007; 357: 1156-1157; author reply 1157-1158.

45. Frisch M, Biggar RJ. Aetiological parallel between tonsillar and anogenital squamous-cell carcinomas. Lancet 1999; 354: 1442-1443. DOI:10.1016/S0140-6736 (99)92824-6

46. Mork J, Lie AK, Glattre E, et al. Human papillomavirus infection as a risk factor for squamous-cell carcinoma of the head and neck. The New England Journal of Medicine 2001; 344: 1125-1131.

47. Hemminki K, Dong C, Frisch M. Tonsillar and other upper aerodigestive tract cancers among cervical cancer patients and their husbands. European Journal of Cancer Prevention 2000; 9: 433-437.

48. Syrjanen K, Syrjanen S, Lamberg M, et al. Morphological and immunohistochemical evidence suggesting human papillomavirus (HPV) involvement in oral squamous cell carcinogenesis. International Journal of Oral Surgery 1983; 12: 418-424. DOI: 10.1016/S0300-9785(83)80033-7

49. Klussmann JP, Weissenborn SJ, Wieland U, et al. Prevalence, distribution, and viral load of human papillomavirus 16 DNA in tonsillar carcinomas. Cancer 2001; 92: 2875-2884.

50. van Houten VM, Snijders PJ, van den Brekel MW, et al. Biological evidence that human papillomaviruses are etiologically involved in a subgroup of head and neck squamous cell carcinomas. International Journal of Cancer 2001; 93: 232-235. DOI: 10.1002/ijc.1313

51. D'Souza G, Agrawal Y, Halpern J, et al. Oral sexual behaviors associated with prevalent oral human papillomavirus infection. Journal of Infectious Diseases 2009; 199: $1263-1269$. DOI: $10.1086 / 597755$

52. Kreimer AR, Clifford GM, Boyle P, et al. Human papillomavirus types in head and neck squamous cell carcinomas worldwide: a systematic review. Cancer Epidemiology, Biomarkers \& Prevention 2005; 14: 467-475.

53. Gillison ML, Koch WM, Capone RB, et al. Evidence for a causal association between human papillomavirus and a subset of head and neck cancers. Journal of the $\mathrm{Na}$ tional Cancer Institute 2000; 92: 709-720.

54. McKaig RG, Baric RS, Olshan AF. Human papillomavirus and head and neck cancer: epidemiology and molecular biology. Head E Neck 1998; 20: 250-265. DOI: $10.1002 /$ (SICI)1097-0347(199805)20:3 < 250::AIDHED11 > 3.0.CO;2-O

55. Chen R, Aaltonen LM, Vaheri A. Human papillomavirus type 16 in head and neck carcinogenesis. Reviews in Medical Virology 2005; 15: 351-363. DOI: 10.1002/rmv.471

56. Mooren JJ, Hopman AHN, Ramaekers FCS, et al. Chromosome stability in tonsillar squamous cell carcinoma is associated with HPV and a favorable prognosis (O191). Oral Oncology Supplement 2009; 3: 119-120. DOI: 10.1016/j.oos.2009.06.276

57. Klingenberg B, Hafkamp HC, Haesevoets A, et al. p16 INK4A overexpression is frequently detected in tumour-free tonsil tissue without association with HPV. Histopathology 2010; 56: 957-967. DOI: 10.1111/j.1365-2559.2010.03576.x

58. Herrero R, Castellsague X, Pawlita M, et al. Human papillomavirus and oral cancer: the International Agency for Research on Cancer multicenter study. Journal of the National Cancer Institute 2003; 95: 1772-1783. DOI: 10.1093/jnci/djg107

59. Smeets SJ, Hesselink AT, Speel EJ, et al. A novel algorithm for reliable detection of human papillomavirus in paraffin embedded head and neck cancer specimen. International Journal of Cancer 2007; 121: 2465-2472. DOI: 10.1002/ijc.22980

60. Lajer CB, von Buchwald C. The role of human papillomavirus in head and neck cancer. APMIS 2010; 118: 510-519. DOI: 10.1111/ j.1600-0463.2010.02624.x

61. Marur S, D'Souza G, Westra WH, et al. HPVassociated head and neck cancer: a virusrelated cancer epidemic. The Lancet Oncology 2010; 11: 781-789. DOI: 10.1016/S1470-2045 (10)70017-6

62. Wiest T, Schwarz E, Enders C, et al. Involvement of intact HPV16 E6/E7 gene expression in head and neck cancers with unaltered p53 status and perturbed pRb cell cycle control. Oncogene 2002; 21: 1510-1517. DOI: 10.1038/sj/onc/1205214

63. Weinberger PM, Yu Z, Haffty BG, et al. Molecular classification identifies a subset of human papillomavirus-associated oropharyngeal cancers with favorable prognosis. Journal of Clinical Oncology 2006; 24: 736-747. DOI: $10.1200 / J C O .2004 .00 .3335$

64. Klussmann JP, Gultekin E, Weissenborn SJ, et al. Expression of p16 protein identifies a distinct entity of tonsillar carcinomas associated with human papillomavirus. American Journal of Pathology 2003; 162: 747-753. DOI:10.1016/S0002-9440(10)63871-0

65. Shi W, Kato H, Perez-Ordonez B, et al. Comparative prognostic value of HPV16 E6 mRNA compared with in situ hybridization for human oropharyngeal squamous carcinoma. Journal of Clinical Oncology 2009; 27: 6213-6221. DOI: 10.1200/JCO.2009.23.1670

66. Hafkamp HC, Mooren JJ, Claessen SM, et al. P21 Cip1/WAF1 expression is strongly associated with HPV-positive tonsillar carcinoma and a favorable prognosis. Modern Pathology 2009; 22: 686-698. DOI:10.1038/ modpathol.2009.23

67. Reimers N, Kasper HU, Weissenborn SJ, et al. Combined analysis of HPV-DNA, p16 and EGFR expression to predict prognosis in oropharyngeal cancer. International Journal of Cancer 2007; 120: 1731-1738. DOI: 10.1002/ijc.22355

68. Klussmann JP, Mooren JJ, Lehnen M, et al. Genetic signatures of HPV-related and unrelated oropharyngeal carcinoma and their prognostic implications. Clinical Cancer 
Research 2009; 15: 1779-1786. DOI: 10.1158/1078-0432.CCR-08-1463

69. Kumar B, Cordell KG, Lee JS, et al. EGFR, p16, HPV Titer, Bcl-xL and p53, sex, and smoking as indicators of response to therapy and survival in oropharyngeal cancer. Journal of Clinical Oncology 2008; 26: 3128-3137. DOI: 10.1200/JCO.2007.12.7662

70. Kim SH, Koo BS, Kang S, et al. HPV integration begins in the tonsillar crypt and leads to the alteration of p16, EGFR and c-myc during tumor formation. International Journal of Cancer 2007; 120: 1418-1425. DOI: 10.1002/ ijc. 22464

71. Kong CS, Narasimhan B, Cao H, et al. The relationship between human papillomavirus status and other molecular prognostic markers in head and neck squamous cell carcinomas. International Journal of Radiation Oncology, Biology, and Physics 2009; 74: 553-561. DOI: 10.1016/j.ijrobp.2009.02.015

72. Leemans CR, Braakhuis BJ, Brakenhoff RH. The molecular biology of head and neck cancer. Nature Reviews. Cancer 2011; 11: $9-22$. DOI: $10.1038 /$ nrc2982

73. Grimminger CM, Danenberg PV. Update of prognostic and predictive biomarkers in oropharyngeal squamous cell carcinoma: a review. European Archives of OtoRhino-Laryngology 2011; 268: 5-16. DOI: 10.1007/s00405-010-1369-x

74. Jung AC, Briolat J, Millon R, et al. Biological and clinical relevance of transcriptionally active human papillomavirus (HPV) infection in oropharynx squamous cell carcinoma. International Journal of Cancer 2010; 126: 1882-1894. DOI: 10.1002/ijc.24911

75. Rincon-Orozco B, Halec G, Rosenberger S, et al. Epigenetic silencing of interferonkappa in human papillomavirus type 16-positive cells. Cancer Research 2009; 69: 8718-8725. DOI: 10.1158/0008-5472. CAN-09-0550

76. Martinez I, Wang J, Hobson KF, et al. Identification of differentially expressed genes in HPV-positive and HPV-negative oropharyngeal squamous cell carcinomas. European Journal of Cancer 2007; 43: 415-432. DOI: 10.1016/j.ejca.2006.09.001

77. Slebos RJ, Yi Y, Ely K, et al. Gene expression differences associated with human papillomavirus status in head and neck squamous cell carcinoma. Clinical Cancer
Research 2006; 12: 701-709. DOI: 10.1158/ 1078-0432.CCR-05-2017

78. Schlecht NF, Burk RD, Adrien L, et al. Gene expression profiles in HPV-infected head and neck cancer. The Journal of Pathology 2007; 213: 283-293. DOI: 10.1002/ path. 2227

79. Wald AI, Hoskins EE, Wells SI, et al. Alteration of microRNA profiles in squamous cell carcinoma of the head and neck cell lines by human papillomavirus. Head E Neck 2010; 33: 504-512. DOI: 10.1002/hed.21475

80. Melle C, Ernst G, Winkler R, et al. Proteomic analysis of human papillomavirusrelated oral squamous cell carcinoma: identification of thioredoxin and epidermalfatty acid binding protein as upregulated protein markers in microdissected tumor tissue. Proteomics 2009; 9: 2193-2201. DOI: 10.1002/pmic. 200800882

81. Clinical practice guidelines in oncology Head and Neck Cancers. http:/ /www.ncen. org. [18-01-2011]

82. Moore EJ, Henstrom DK, Olsen KD, et al. Transoral resection of tonsillar squamous cell carcinoma. Laryngoscope 2009; 119: 508-515. DOI: 10.1002/lary.20124

83. Park YM, Lee JG, Lee WS, et al. Feasibility of transoral lateral oropharyngectomy using a robotic surgical system for tonsillar cancer. Oral Oncology 2009; 45: e62-66. DOI:10.1016/j.oraloncology.2009.02.012

84. Haigentz M, Jr., Silver CE, Corry J, et al. Current trends in initial management of oropharyngeal cancer: the declining use of open surgery. European Archives of OtoRhino-Laryngology 2009; 266: 1845-1855. DOI: $10.1007 /$ s00405-009-1109-2

85. Corvo R. Evidence-based radiation oncology in head and neck squamous cell carcinoma. Radiotherapy and Oncology 2007; 85: 156-170. DOI: 10.1016/j.radonc.2007.04.002

86. Sobin L, Gosposarowics M, Wittekind C. Head and neck. In: TNM Classification of malignant Tumors, O'Sullivan B (ed). WileyBlackwell: West-Sussex, 2010; 17-50.

87. Lindel K, Beer KT, Laissue J, et al. Human papillomavirus positive squamous cell carcinoma of the oropharynx: a radiosensitive subgroup of head and neck carcinoma. Cancer 2001; 92: 805-813.

88. Ringstrom E, Peters E, Hasegawa M, et al. Human papillomavirus type 16 and squamous cell carcinoma of the head and neck. Clinical Cancer Research 2002; 8: 3187-3192.

89. Fischer CA, Zlobec I, Green E, et al. Is the improved prognosis of $\mathrm{p} 16$ positive oropharyngeal squamous cell carcinoma dependent of the treatment modality? International Journal of Cancer 2010; 126: 1256-1262. DOI: 10.1002/ijc.24842

90. Fallai C, Perrone F, Licitra L, et al. Oropharyngeal squamous cell carcinoma treated with radiotherapy or radiochemotherapy: prognostic role of TP53 and HPV status. International Journal of Radiation Oncology, Biology, and Physics 2009; 75: 1053-1059. DOI: 10.1016/j.ijrobp.2008.12.088

91. Lassen P, Eriksen JG, Hamilton-Dutoit S, et al. Effect of HPV-associated p16INK4A expression on response to radiotherapy and survival in squamous cell carcinoma of the head and neck. Journal of Clinical Oncology 2009; 27: 1992-1998. DOI: 10.1200/ JCO.2008.20.2853

92. Fakhry C, Westra WH, Li S, et al. Improved survival of patients with human papillomavirus-positive head and neck squamous cell carcinoma in a prospective clinical trial. Journal of the National Cancer Institute 2008; 100: 261-269. DOI: 10. 1093/jnci/djn011

93. Maxwell JH, Kumar B, Feng FY, et al. Tobacco use in human papillomavirus-positive advanced oropharynx cancer patients related to increased risk of distant metastases and tumor recurrence. Clinical Cancer Research 2010; 16: 1226-1235. DOI: 10. 1158/1078-0432.CCR-09-2350

94. Ang KK, Harris J, Wheeler R, et al. Human papillomavirus and survival of patients with oropharyngeal cancer. The New England Journal of Medicine 2010; 363: 24-35.

95. Lassen P. The role of human papillomavirus in head and neck cancer and the impact on radiotherapy outcome. Radiotherapy and Oncology 2010; 95: 371-380. DOI: 10.1016/j.radonc.2010.04.022

96. Psyrri A, Gouveris P, Vermorken JB. Human papillomavirus-related head and neck tumors: clinical and research implication. Current Opinion in Oncology 2009; 21: 201-205. DOI: 10.1097/CCO.0b013e328329ab64

97. Marur S. Paclitaxel, cisplatin, and cetuximab followed by cetuximab and intensity- 
modulated radiation therapy in treating patients with HPV-associated stage III or stage IV cancer of the oropharynx that can be removed by surgery. NCT01084083, 2010. http://clinicaltrials.gov

98. Centres for disease control and prevention (CDC). FDA licensure of bivalent human papillomavirus vaccine (HPV2, Cervarix) for use in females and updated HPV vaccination recommendations from the Advisory Committee on Immunization Practices (ACIP). MMWR Morbidity and Mortal Weekly Report 2010; 59: 626-629.

99. Markowitz LE, Dunne EF, Saraiya M, et al. Quadrivalent human papillomavirus vaccine: recommendations of the advisory committee on immunization practices (ACIP). MMWR Recommendations and Reports 2007; 56: 1-24.

100. Centres for disease control and prevention (CDC). FDA licensure of quadrivalent human papillomavirus vaccine (HPV4, Gardasil) for use in males and guidance from the Advisory Committee on Immunization Practices (ACIP). MMWR Morbidity and Mortality Weekly Report 2010; 59: 630-632.

101. Jenkins D. A review of cross-protection against oncogenic HPV by an HPV-16/18 AS04-adjuvanted cervical cancer vaccine: importance of virological and clinical endpoints and implications for mass vaccination in cervical cancer prevention. Gynecologic Oncology 2008; 110: S18-25. DOI:10.1016/j.ygyno.2008.06.027

102. Paavonen J, Naud P, Salmeron J, et al. Efficacy of human papillomavirus (HPV)-16/18 AS04-adjuvanted vaccine against cervical infection and precancer caused by oncogenic HPV types (PATRICIA): final analysis of a double-blind, randomised study in young women. Lancet 2009; 374: 301-314. DOI:10. 1016/S0140-6736(09)61248-4

103. Brown DR, Kjaer SK, Sigurdsson K, et al. The impact of quadrivalent human papillomavirus (HPV; types 6, 11, 16, and 18) L1 virus-like particle vaccine on infection and disease due to oncogenic nonvaccine HPV types in generally HPV-naive women aged 16-26years. Journal of Infectious Diseases 2009; 199: 926-935. DOI: $10.1086 / 597307$

104. Jagu S, Kwak K, Garcea RL, et al. Vaccination with multimeric L2 fusion protein and L1 VLP or capsomeres to broaden protection against
HPV infection. Vaccine 2010; 28: 4478-4486. DOI: 10.1016/j.vaccine.2010.04.039

105. Joura EA, Kjaer SK, Wheeler CM, et al. HPV antibody levels and clinical efficacy following administration of a prophylactic quadrivalent HPV vaccine. Vaccine 2008; 26: 6844-6851. DOI: 10.1016/ j.vaccine.2008.09.073

106. Olsson SE, Kjaer SK, Sigurdsson K, et al. Evaluation of quadrivalent HPV 6/11/ $16 / 18$ vaccine efficacy against cervical and anogenital disease in subjects with serological evidence of prior vaccine type HPV infection. Human Vaccines 2009; 5: 696-704.

107. Munoz N, Manalastas R, Jr., Pitisuttithum P, et al. Safety, immunogenicity, and efficacy of quadrivalent human papillomavirus (types $6,11,16,18$ ) recombinant vaccine in women aged 24-45years: a randomised, doubleblind trial. Lancet 2009; 373: 1949-1957. DOI: 10.1016/S0140-6736(09)60691-7

108. Hung CF, Ma B, Monie A, et al. Therapeutic human papillomavirus vaccines: current clinical trials and future directions. Expert Opinion on Biological Therapy 2008; 8: 421-439. DOI:10.1517/14712598.8.4.421

109. Einstein MH, Kadish AS, Burk RD, et al. Heat shock fusion protein-based immunotherapy for treatment of cervical intraepithelial neoplasia III. Gynecologic Oncology 2007; 106: 453-460. DOI:10.1016/j.ygyno.2007.04.038

110. Santin AD, Bellone S, Palmieri M, et al. Human papillomavirus type 16 and 18 E7-pulsed dendritic cell vaccination of stage IB or IIA cervical cancer patients: a phase I escalating-dose trial. Journal of $\mathrm{Vi}$ rology 2008; 82: 1968-1979. DOI:10.1128/ JVI.02343-07

111. Trimble CL, Frazer IH. Development of therapeutic HPV vaccines. The Lancet Oncology 2009; 10: 975-980. DOI: 10.1016/ S1470-2045(09)70227-X

112. Wu A, Zeng Q, Kang TH, et al. Innovative DNA vaccine for human papillomavirus (HPV)-associated head and neck cancer. Gene Therapy 2011; 18: 304-312. DOI:10.1038/ gt.2010.151

113. Edelman M. MAGE-A3/HPV 16 vaccine for squamous cell carcinoma of the head and neck. NCT00257738, 2005. http:/ / clinicaltrials.gov

114. Edelman M. Four doses of MAGE vaccine for patients with squamous cell carcinoma of the head and neck. NCT00704041, 2009. http://clinicaltrials.gov

115. Mak T, Saunders M. Cytokines and cytokine receptors. In: The immune response - basic and clinical principles, Picknett T, Lebedeva V (ed). Elsevier Academic Press: Oxford, 2006; 464-517.

116. Beglin M, Melar-New M, Laimins L. Human papillomaviruses and the interferon response. Journal of Interferon \& Cytokine Research 2009; 29: 629-635. DOI:10.1089/jir.2009.0075

117. Nees M, Geoghegan JM, Hyman T, et al. Papillomavirus type 16 oncogenes downregulate expression of interferon-responsive genes and upregulate proliferation-associated and NFkappaB-responsive genes in cervical keratinocytes. Journal of Virology 2001; 75: 4283-4296. DOI: 10.1128/JVI.75.9.4283-4296.2001

118. de Jong A, van der Burg SH, Kwappenberg KM, et al. Frequent detection of human papillomavirus 16 E2-specific T-helper immunity in healthy subjects. Cancer Research 2002; 62: 472-479.

119. Welters MJ, de Jong A, van den Eeden SJ, et al. Frequent display of human papillomavirus type 16 E6-specific memory T-helper cells in the healthy population as witness of previous viral encounter. Cancer Research 2003; 63: 636-641.

120. Yang J, Pu YG, Zeng ZM, et al. Interferon for the treatment of genital warts: a systematic review. BMC Infectious Diseases 2009; 9: 156. DOI:10.1186/1471-2334-9-156

121. Gonzalez-Sanchez JL, Martinez-Chequer JC, Hernandez-Celaya ME, et al. Randomized placebo-controlled evaluation of intramuscular interferon beta treatment of recurrent human papillomavirus. Obstetrics and Gynecology 2001; 97: 621-624.

122. Syed TA, Ahmadpour OA. Human leukocyte derived interferon-alpha in a hydrophilic gel for the treatment of intravaginal warts in women: a placebo-controlled, double-blind study. International Journal of STD and AIDS 1998; 9: 769-772.

123. Bornstein J, Pascal B, Zarfati D, et al. Recombinant human interferon-beta for condylomata acuminata: a randomized, double-blind, placebo-controlled study of intralesional therapy. International Journal of STD and AIDS 1997; 8: 614-621.

124. Yliskoski M, Syrjanen K, Syrjanen S, et al. Systemic alpha-interferon (Wellferon) treatment of genital human papillomavirus (HPV) type 6, 11, 16, and 18 infections: double-blind, 
placebo-controlled trial. Gynecologic Oncology 1991; 43: 55-60.

125. Chang YE, Pena L, Sen GC, et al. Longterm effect of interferon on keratinocytes that maintain human papillomavirus type 31. Journal of Virology 2002; 76: 8864-8874. DOI: $10.1128 / J V I .76 .17 .8864-8874.2002$

126. Herdman MT, Pett MR, Roberts I, et al. Interferon-beta treatment of cervical keratinocytes naturally infected with human papillomavirus 16 episomes promotes rapid reduction in episome numbers and emergence of latent integrants. Carcinogenesis 2006; 27: 2341-2353. DOI: $10.1093 /$ carcin/bgl172

127. Saikia P, Fensterl V, Sen GC. The inhibitory action of P56 on select functions of E1 mediates interferon's effect on human papillomavirus DNA replication. Journal of Virology 2010; 84: 13036-13039. DOI: 10.1128/JVI.01194-10

128. Terenzi F, Saikia P, Sen GC. Interferoninducible protein, P56, inhibits HPV DNA replication by binding to the viral protein E1. EMBO Journal 2008; 27: 3311-3321. DOI: $10.1038 /$ emboj. $\quad 2008.241$

129. Lace MJ, Anson JR, Klingelhutz AJ, et al. Interferon-beta treatment increases human papillomavirus early gene transcription and viral plasmid genome replication by activating interferon regulatory factor (IRF)-1. Carcinogenesis 2009; 30: 1336-1344.

130. Gerein V, Rastorguev E, Gerein J, et al. Use of interferon-alpha in recurrent respiratory papillomatosis: 20-year follow-up. Annals of Otology, Rhinology and Laryngology 2005; 114: 463-471.

131. De Clercq E. Antiviral drug discovery and development: where chemistry meets with biomedicine. Antiviral Research 2005; 67: 56-75. DOI: 10.1016/j.antiviral.2005.05.001

132. Abdulkarim B, Sabri S, Deutsch E, et al. Antiviral agent Cidofovir restores p53 function and enhances the radiosensitivity in HPV-associated cancers. Oncogene 2002; 21: 2334-2346. DOI: $10.1038 / \mathrm{sj} /$ onc/ 1205006

133. Andrei G, Snoeck R, Schols D, et al. Induction of apoptosis by cidofovir in human papillomavirus (HPV)-positive cells. Oncology Research 2000; 12: 397-408.

134. Andrei G, Snoeck R, Piette J, et al. Antiproliferative effects of acyclic nucleoside phosphonates on human papillomavirus
(HPV)-harboring cell lines compared with HPV-negative cell lines. Oncology Research 1998; 10: 523-531.

135. Spanos WC, El-Deiry M, Lee JH. Cidofovir incorporation into human keratinocytes with episomal HPV 16 results in nonselective cytotoxicity. Annals of Otology, Rhinology and Laryngology 2005; 114: 840-846.

136. Sirianni N, Wang J, Ferris RL. Antiviral activity of Cidofovir on a naturally human papillomavirus-16 infected squamous cell carcinoma of the head and neck (SCCHN) cell line improves radiation sensitivity. Oral Oncology 2005; 41: 423-428. DOI: 10.1016/j.oraloncology.2004.11.003

137. Park J, Kommareddi P, Nair T, et al. Cidofovir modulates HPV E6 and E7 as well as p53, Rb and MDM2 in HPV16 naturally transformed head and neck squamous cell carcinoma and enhances chemosensitivity to cisplatin. Proceedings of the American Association for Cancer Research. Orlando, Fl, USA. 2011.

138. Donne AJ, Hampson L, He XT, et al. Potential risk factors associated with the use of cidofovir to treat benign human papillomavirus-related disease. Antiviral Therapy 2009; 14: 939-952.

139. Donne AJ, Rothera MP, Homer JJ. Scientific and clinical aspects of the use of cidofovir in recurrent respiratory papillomatosis. International Journal of Pediatric Otorhinolaryngology 2008; 72: 939-944. DOI: 10.1016/j. ijporl.2008.04.003

140. Wolf DL, Rodriguez CA, Mucci M, et al. Pharmacokinetics and renal effects of cidofovir with a reduced dose of probenecid in HIV-infected patients with cytomegalovirus retinitis. Journal of Clinical Pharmacology 2003; 43: 43-51. DOI: 10.1177/0091270002239705

141. Snoeck R, Noel JC, Muller C, et al. Cidofovir, a new approach for the treatment of cervix intraepithelial neoplasia grade III (CIN III). Journal of Medical Virology 2000; 60: 205-209. DOI: $10.1002 /(\mathrm{SICI}) 1096-9071(200002) 60: 2$ $<205$ ::AID-JMV16>3.0.CO;2-8

142. Van Pachterbeke C, Bucella D, Rozenberg $\mathrm{S}$, et al. Topical treatment of CIN 2+ by cidofovir: results of a phase II, doubleblind, prospective, placebo-controlled study. Gynecologic Oncology 2009; 115: 69-74. DOI: 10.1016/j.ygyno.2009.06.042
143. Snoeck R, Bossens M, Parent D, et al. Phase II double-blind, placebo-controlled study of the safety and efficacy of cidofovir topical gel for the treatment of patients with human papillomavirus infection. Clinical Infectious Diseases 2001; 33: 597-602. DOI: $10.1086 / 322593$

144. Tristram A, Fiander A. Clinical responses to Cidofovir applied topically to women with high grade vulval intraepithelial neoplasia. Gynecologic Oncology 2005; 99: 652-655. DOI:10.1016/j.ygyno.2005.07.127

145. Petersen BL, Buchwald C, Gerstoft J, et al. An aggressive and invasive growth of juvenile papillomas involving the total respiratory tract. Journal of Laryngology and Otology 1998; 112: 1101-1104.

146. Deutsch E. Cidofovir in treating patients with stage IB, stage II, stage III, or stage IVA cervical cancer who are receiving chemotherapy and radiation therapy. NCT00811408, 2008. http://clinicaltrials.gov

147. Chen XZ, Zhu KJ, Xu Y, et al. RNA interference silences the human papillomavirus $6 \mathrm{~b} / 11$ early gene E7 in vitro and in vivo. Clinical and Experimental Dermatology 2010; 35: 509-515. DOI: 10.1111/j.13652230.2009.03624.x

148. Butz K, Ristriani T, Hengstermann A, et al. siRNA targeting of the viral E6 oncogene efficiently kills human papillomaviruspositive cancer cells. Oncogene 2003; 22: 5938-5945. DOI: 10.1038/sj.onc.1206894

149. Rampias T, Sasaki C, Weinberger P, et al. E6 and E7 gene silencing and transformed phenotype of human papillomavirus 16-positive oropharyngeal cancer cells. Journal of the National Cancer Institute 2009; 101: 412-423. DOI: 10.1093/jnci/djp017

150. Sima N, Wang W, Kong D, et al. RNA interference against HPV16 E7 oncogene leads to viral E6 and E7 suppression in cervical cancer cells and apoptosis via upregulation of $\mathrm{Rb}$ and p53. Apoptosis 2008; 13: 273-281. DOI: 10.1007/s10495-007-0163-8

151. Yamato K, Yamada T, Kizaki M, et al. New highly potent and specific E6 and E7 siRNAs for treatment of HPV16 positive cervical cancer. Cancer Gene Therapy 2008; 15: 140-153. DOI:10.1038/sj.cgt.7701118

152. Putral LN, Bywater MJ, Gu W, et al. RNA interference against human papillomavirus oncogenes in cervical cancer cells results in 
increased sensitivity to cisplatin. Molecular Pharmacology 2005; 68: 1311-1319. DOI: 10.1124/mol.105.014191

153. Merlano M, Russi E, Benasso M, et al. Cisplatinbased chemoradiation plus cetuximab in locally advanced head and neck cancer: a phase II clinical study. Annals of Oncology 2011; 22: 712-717. DOI: 10.1093/annonc/mdq412

154. Gaffney DK, Haslam D, Tsodikov A, et al. Epidermal growth factor receptor (EGFR) and vascular endothelial growth factor (VEGF) negatively affect overall survival in carcinoma of the cervix treated with radiotherapy. International Journal of Radiation Oncology, Biology, and Physics 2003; 56: 922-928. DOI:10.1016/S0360-3016(03)00209-8

155. Kummel S, Heidecke H, Brock B, et al. Imatinib--a possible therapeutic option for cervical carcinoma: results of a preclinical phase I study. Gynäkologisch-Geburtshilfliche Rundschau 2008; 48: 94-100. DOI: 10.1159/000119032

156. Karin M, Greten FR. NF-kappaB: linking inflammation and immunity to cancer development and progression. Nature Reviews Immunology 2005; 5: 749-759. DOI: $10.1038 /$ nri1703

157. Molinolo AA, Amornphimoltham P, Squarize $\mathrm{CH}$, et al. Dysregulated molecular networks in head and neck carcinogenesis. Oral Oncology 2009; 45: 324-334. DOI: 10.1016/j.oraloncology.2008.07.011

158. Straetmans JM, Olthof N, Mooren JJ, et al. Human papillomavirus reduces the prognostic value of nodal involvement in tonsillar squamous cell carcinomas. Laryngoscope 2009; 119: 1951-1957. DOI: 10.1002/ lary.20593

159. Stenner M, Yosef B, Huebbers CU, et al. Nuclear translocation of beta-catenin and decreased expression of epithelial cadherin in human papillomavirus-positive tonsillar cancer: an early event in human papillomavirus-related tumour progression? Histopathology 2011; 10.1111/j.13652559.2011.03805.x

160. Soo K. Study of post-op adjuvant concurrent chemo-RT with or without nimotuzumab for head \& neck cancer. NCT00957086, 2009. http://clinicaltrials.gov

161. Schmidtke G, Holzhutter HG, Bogyo M, et al. How an inhibitor of the HIV-I protease modulates proteasome activity. Journal of Biological
Chemistry 1999; 274: 35734-35740. DOI: 10.1074/jbc.274.50.35734

162. Hampson L, Kitchener HC, Hampson IN. Specific HIV protease inhibitors inhibit the ability of HPV16 E6 to degrade p53 and selectively kill E6-dependent cervical carcinoma cells in vitro. Antiviral Therapy 2006; 11: 813-825.

163. Mino T, Hatono T, Matsumoto N, et al. Inhibition of DNA replication of human papillomavirus by artificial zinc finger proteins. Journal of Virology 2006; 80: 5405-5412. DOI:10.1128/JVI.01795-05

164. Mino T, Mori T, Aoyama Y, et al. Cellpermeable artificial zinc-finger proteins as potent antiviral drugs for human papillomaviruses. Archives of Virology 2008; 153: 1291-1298. DOI: 10.1007/s00705-008-0125-7

165. Lepique AP, Daghastanli KR, Cuccovia $\mathrm{IM}$, et al. HPV16 tumor associated macrophages suppress antitumor $\mathrm{T}$ cell responses. Clinical Cancer Research 2009; 15: 4391-4400. DOI: 10.1158/1078-0432. CCR-09-0489

166. Visser J, Nijman HW, Hoogenboom BN, et al. Frequencies and role of regulatory $\mathrm{T}$ cells in patients with (pre)malignant cervical neoplasia. Clinical and Experimental Immunology 2007; 150: 199-209. DOI: 10.1111/j.1365-2249.2007.03468.x.

167. Chuang CM, Hoory T, Monie A, et al. Enhancing therapeutic HPV DNA vaccine potency through depletion of CD4 + CD25+ T regulatory cells. Vaccine 2009; 27: 684-689. DOI: 10.1016/j.vaccine.2008.11.042

168. Mahto M, Nathan M, O'Mahony C. More than a decade on: review of the use of imiquimod in lower anogenital intraepithelial neoplasia. International Journal of STD and AIDS 2010; 21: 8-16. DOI:10.1258/ijsa.2009.009309

169. Lucker GP, Speel EJ, Creytens DH, et al. Differences in imiquimod treatment outcome in two patients with bowenoid papulosis containing either episomal or integrated human papillomavirus 16. The Journal of Investigative Dermatology 2007; 127: 727-729. DOI:10.1038/s.j.ji.5700578

170. Johnson JA, Gangemi JD. Alpha interferon augments cidofovir's antiviral and antiproliferative activities. Antimicrobial Agents and Chemotherapy 2003; 47: 2022-2026. DOI: 10.1128/AAC.47.6.2022-2026.2003

171. Benson J, Bramlage B, Fitzgerald K, et al. dsRNA compositions and methods for treating HPV infection. Alnylam Pharmaceuticals Inc. 2011. http:/ / www.freepatentsonline.com

172. Doorbar J. Molecular biology of human papillomavirus infection and cervical cancer. Clinical Science (London, England) 2006; 110: 525-541. DOI:10.1042/CS20050369

173. Ganguly N, Parihar SP. Human papillomavirus E6 and E7 oncoproteins as risk factors for tumorigenesis. Journal of Biosciences 2009; 34: 113-123.

174. Hafkamp HC, Manni JJ, Speel EJ. Role of human papillomavirus in the development of head and neck squamous cell carcinomas. Acta Oto-Laryngologica 2004; 124: 520-526. DOI 10.1080/00016480310016893

175. Hamid NA, Brown C, Gaston K. The regulation of cell proliferation by the papillomavirus early proteins. Cellular and Molecular Life Sciences 2009; 66: 1700-1717. DOI:10.1042/ CS20050369

176. Beaudenon S, Praetorius F, Kremsdorf D, et al. A new type of human papillomavirus associated with oral focal epithelial hyperplasia. The Journal of Investigative Dermatology 1987; 88: 130-135.

177. Cuberos V, Perez J, Lopez CJ, et al. Molecular and serological evidence of the epidemiological association of HPV 13 with focal epithelial hyperplasia: a case-control study. Journal of Clinical Virology 2006; 37: 21-26. DOI:10.1016/j.jcv.2006.04.003

178. Altavilla G, Staffieri A, Busatto G, et al. Expression of p53, p16INK4A, pRb, p21WAF1/CIP1, p27KIP1, cyclin D1, Ki67 and HPV DNA in sinonasal endophytic Schneiderian (inverted) papilloma. Acta Oto-Laryngologica 2009; 129: 1242-1249.

179. Syrjanen KJ. HPV infections in benign and malignant sinonasal lesions. Journal of Clinical Pathology 2003; 56: 174-181. DOI: 10.1136/jcp.56.3.174

180. Goon P, Sonnex C, Jani P, et al. Recurrent respiratory papillomatosis: an overview of current thinking and treatment. European Archives of Oto-Rhino-Laryngology 2008; 265: 147-151. DOI: 10.1007/s00405007-0546-z

181. Stamataki S, Nikolopoulos TP, Korres S, et al. Juvenile recurrent respiratory papillomatosis: still a mystery disease with difficult management. Head \& Neck 2007; 29: 155-162. DOI: 10.1002/hed.20491 
182. Campisi G, Giovannelli L, Arico P, et al. HPV DNA in clinically different variants of oral leukoplakia and lichen planus. Oral Surgery, Oral Medicine, Oral Pathology, Oral Radiology, and Endodontics 2004; 98: 705-711. DOI:10.1016/j.tripleo.2004.04.012

183. Yang SW, Lee YS, Chen TA, et al. Human papillomavirus in oral leukoplakia is no prognostic indicator of malignant transformation. Cancer Epidemiology 2009; 33: 118-122. DOI: 10.1016/j. canep.2009.05.003

184. Barzon L, Militello V, Pagni S, et al. Distribution of human papillomavirus type in the anogenital tract of females and males. Journal of Medical Virology 2010; 82: 14241430. DOI: $10.1002 / j m v .21733$

185. Bulk S, Berkhof J, Bulkmans NW, et al. Preferential risk of HPV16 for squamous cell carcinoma and of HPV18 for adenocarcinoma of the cervix compared to women with normal cytology in The Netherlands. British Journal of Cancer 2006; 94: 171-175. DOI: $10.1038 /$ sj.bjc.6602915

186. Castellsague X, Diaz M, de Sanjose S, et al. Worldwide human papillomavirus etiology of cervical adenocarcinoma and its cofactors: implications for screening and prevention. Journal of the National Cancer Institute 2006; 98: 303-315. DOI: 10.1093/jnci/dij067

187. Severson J, Evans TY, Lee P, et al. Human papillomavirus infections: epidemiology, pathogenesis, and therapy. Journal of Cutaneous Medicine and Surgery 2001; 5: 43-60.

188. Ashinoff R, Li JJ, Jacobson M, et al. Detection of human papillomavirus DNA in squamous cell carcinoma of the nail bed and finger determined by polymerase chain reaction. Archives of Dermatology 1991; 127: 1813-1818.

189. Kreuter A, Gambichler T, Pfister H, et al. Diversity of human papillomavirus types in periungual squamous cell carcinoma. British Journal of Dermatology 2009; 161: 1262-1269. DOI: 10.1111/j.1365-2133.2009. 09343.x

190. Li W, Thompson CH, O’Brien CJ, et al. Human papillomavirus positivity predicts favourable outcome for squamous carcinoma of the tonsil. International Journal of Cancer 2003; 106: 553-558. DOI: 10.1002/ ijc. 11261

191. Mao L, Hong WK, Papadimitrakopoulou VA. Focus on head and neck cancer. Cancer Cell 2004; 5: 311-316. DOI: 10.1016/S1535-6108(04) 00090-X

192. Ritchie JM, Smith EM, Summersgill KF, et al. Human papillomavirus infection as a prognostic factor in carcinomas of the oral cavity and oropharynx. International Journal of Cancer 2003; 104: 336-344. DOI: 10.1002/ijc. 10960 